\title{
STUDIES ON NEMATODE PARASITES INFECTING FRESHWATER FISH IN QENA GOVERNORATE
}

M. A. Elseify ${ }^{*}$, I.S. El Shihawy ${ }^{* *}$, A. M. Metwally ${ }^{* *}$ and M. Fawaz $^{* * *}$ Faculty of Veterinary Medicine, Department of Parasitology, Kafrelsheikh University* South Valley University, ** Egypt,

\begin{abstract}
The present study was carried out to make a spot light on nematode parasites infecting Freshwater fish at Qena Governorate; including prevalence, seasonal dynamics of infection; intensity and morphology of the recovered parasite species.

It was found that the infection rate of different nematode among freshwater fish in Qena Governorate was (13\%). Lates niloticus has highest infection rate (27.8\%) followed by Carias gariepinus (8.3\%) the Oreochromis niloticus (2.3\%). Concerning the seasonal prevalence Winter has highest infection rate followed by Autumn then Summer and Spring. Four nematodes were recovered and identified as Paracamallanus cyathopharynx (2.8\%) in Clarias lazera; Procamallanus laevionchus (2.8\%) in Clarias lazera; Contracaecum sp. (2.8\%) in Oreochromis niloticus and Clarias lazera and (26.4\%) in Lates niloticus and Dichelyne niloticus (4.2\%) in Lates niloticus. The mean intensity of infection of Contracaecum sp. among Oreochromis niloticus., Clarias gariepinus and Lates niloticus was $2 \%, 22 \%$ and $20 \%$ respectively.
\end{abstract}




\section{INTRODUCTION}

Fish parasites and diseases constitute one of the most important problems confronting the fishery biologist today (Ravichandran et al. 2007). Pathological conditions resulting from parasites and diseases assume high magnitude of epidemics under crowded and other unnatural conditions (Ravichandran et al., 2010) Gut helminthes, such as trematodes, cestodes, nematodes don't induce severe damage to the vertebrate gastrointestinal tract (Dezfuli, et. al, 2003), unless they are found in large numbers, when they induce growth retardation (Tonguthai, 1997) or mechanical blockage at the gut lumen.

\section{MATERIAL AND METHODS}

\section{a- Collection of fish samples:}

A total of 216 fish samples representing 3 fish species 72 Oreochromis niloticus (Boulti), 72 Clarias lazera (Carmoot) and 72 Lates niloticus (Kishr-bayad) were collected either alive from fishermen or fresh as possible from fish markets at Qena Governorate (Qena city, Abu-Tisht and Nag-Hamady) and submitted for Nematode investigation during the period extended from the beginning of April, 2012 to the end of March, 2013. The collected fish samples were transferred to the laboratory of Parasitology Department; Faculty of Veterinary MedicineSouth Valley University in ice box after packed in plastic bags, labeled with different data about the investigated fish specimens as fish species, date and the site of collection.

\section{b- Collection and preparation of the detected parasites}

The collected nematodes were killed and stretched in hot $70 \%$ ethyl alcohol. Subsequently, after preserving in 70\% alcohol and 5\% glyecrin solution; they were cleared in Lactophenol for several hours according to the thickness of the worms and finally mounted in glycerin jelly preparation and cover with a cover glass (Belding, 1965). 


\section{RESULTS}

\section{I-1 Prevalence of the parasitic infection among examined fish at Qena governorate:}

The results of the present investigation indicated that out of 216 examined fish, 28 samples proved to be infected with Nematode parasites at Qena Governorate with total infection rate of $13 \%$. Concerning the fish species, the obtained results showed that Lates niloticus had the highest infection rate $(27.8 \%)$, followed by Carias gariepinus $(8.3 \%)$, while Oreochromis niloticus represented the lowest percent of infection (2.8\%) as shown in Table (1).

\section{I-2- Seasonal prevalence of the parasitic infection among examined fish at Qena Governorate:}

Table (2) summarized the seasonal prevalence of the recovered nematodes among the examined fish at Qena Governorate. It was concluded that Latus niloticus has the highest infection rate in winter (44.4\%) followed by Autumn (38.9\%) then Summer and Spring $(16.7 \%)$. The prevalence rate of nematode in Tilapia sp. was $0 \%, 0 \%$, $5.6 \%$ and $5.6 \%$ in Winter, Spring, Summer and Autumn respectively. Dealing with the seasonal dynamics of Clarias lazera, the highest infection rate was recorded in Summer and Autumn (11.1\%), followed by $5.6 \%$ in Winter and Spring.

\section{I-3- Identification of the recovered parasites among examined fish at Qena Governorate:}

Table (3) show that four nematodes recovered were identified as Paracamallanus cyathopharynx (2.8\%)in Calarias lazera; Procamallanus laevionchus (2.8\%) in Calarias lazera; Contracaecum sp. $(2.8 \%$ in Oreochromis niloticus. and Calarias lazera and $26.4 \%$ in Lates 
niloticus) and Dichelyne niloticus (4.2\%) in Lates niloticus. The mean intensity of infection of Contracaecum sp. among Oreochromis niloticus., Carias gariepinus and Lates niloticu was 2\%, 22\% and $20 \%$ respectively.

Table (1): Prevalence of different nematode parasites among the examined fish at Qena Governorate:

\begin{tabular}{|c|c|c|c|}
\hline \multirow{2}{*}{ Fish species } & \multirow{2}{*}{ No. of Examined fish } & \multicolumn{2}{|c|}{ Nematodes } \\
\hline & & No. & $\%$ \\
\hline Oreochromis niloticus. & 72 & 2 & 2.8 \\
\hline Clarias gariepinus & 72 & 6 & 8.3 \\
\hline Lates niloticus & 72 & 20 & 27.8 \\
\hline Total & 216 & 28 & 13 \\
\hline
\end{tabular}

Table (2): Monthly and seasonal prevalence of nematodes among Freshwater fish at Qena Governorate:

\begin{tabular}{|c|c|c|c|c|c|c|c|}
\hline & \multicolumn{3}{|c|}{ Oreochromis niloticus } & \multicolumn{2}{|c|}{ Lates niloticus } & \multicolumn{2}{|c|}{ Clarias gariepinus } \\
\hline & $\begin{array}{c}\text { No. of Examined } \\
\text { fish }\end{array}$ & No. & $\%$ & No. & $\%$ & No. & $\%$ \\
\hline December & 6 & 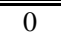 & 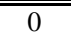 & 2 & 33.3 & 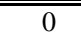 & 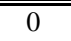 \\
\hline January & 6 & 0 & 0 & 4 & 66.7 & 0 & 0 \\
\hline February & 6 & 0 & 0 & 2 & 33.3 & 1 & 16.7 \\
\hline Winter & 18 & $\overline{\mathbf{0}}$ & $\mathbf{0}$ & 8 & 444.4 & 1 & 5.6 \\
\hline March & 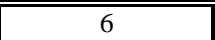 & 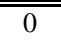 & 0 & 2 & 33.3 & $\overline{0}$ & 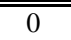 \\
\hline April & 6 & 0 & 0 & 1 & 16.7 & 1 & 16.7 \\
\hline May & 6 & 0 & 0 & 0 & 0 & 0 & 0 \\
\hline Spring & $\overline{18}$ & $\overline{\mathbf{0}}$ & $\overline{\mathbf{0}}$ & $\overline{3}$ & 16.7 & $\overline{1}$ & $\overline{5.6}$ \\
\hline June & 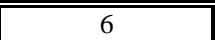 & 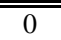 & 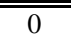 & 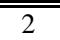 & 33.3 & 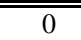 & 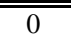 \\
\hline July & 6 & 1 & 16.7 & 1 & 16.7 & 0 & 0 \\
\hline August & 6 & 0 & 0 & 0 & 0 & 2 & 33.3 \\
\hline Summer & $\overline{\overline{18}}$ & $\overline{11}$ & 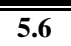 & $\overline{\mathbf{3}}$ & $\overline{10.7}$ & $\overline{2}$ & 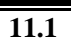 \\
\hline 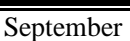 & $\overline{\overline{6}}$ & $\overline{1}$ & $\bar{~} 16.7$ & 3 & $\overline{50}$ & $\overline{1} 1$ & $\bar{~} 16.7$ \\
\hline October & 6 & 0 & 0 & 3 & 50 & 1 & 16.7 \\
\hline November & 6 & 0 & 0 & 1 & 16.7 & 0 & 0 \\
\hline$\overline{\text { Autumn }}$ & $\overline{18}$ & $\overline{1}$ & 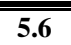 & $\overline{77}$ & 38.9 & $\overline{2}$ & 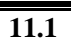 \\
\hline
\end{tabular}

Kafrelsheikh Vet. Med. J. Vol. 13 No. 1 (2015) 
Studies On Nematode Parasites Infecting Freshwater Fish In ...

Table (3): Prevalence of different species of nematode parasites among examined fish at Qena Governorate:

\begin{tabular}{|c|c|c|c|c|}
\hline Helminth species & Fish species & No. of examined fish & No. of infected & $\%$ \\
\hline $\begin{array}{l}\text { Paracamallanus } \\
\text { cyathopharynx }\end{array}$ & Clarias lazera & 72 & 2 & 2.8 \\
\hline Procamallanus laevionchus & Clarias lazera & 72 & 2 & 2.8 \\
\hline Contracaecum $\mathrm{sp}$ & $\begin{array}{c}\text { Oreochromis niloticus } \\
\text { Clarias lazera } \\
\text { Lates niloticus }\end{array}$ & $\begin{array}{l}72 \\
72 \\
72\end{array}$ & $\begin{array}{c}2 \\
2 \\
19\end{array}$ & $\begin{array}{r}2.8 \\
2.8 \\
26.4\end{array}$ \\
\hline Dichelyne niloticus & Lates niloticus & 72 & 3 & 4.2 \\
\hline
\end{tabular}

Table (4): Morphological description of the recovered Nematodes from the examined fish:

\begin{tabular}{|c|c|c|c|}
\hline Parasites & Habitat & Common morphological features & Remarks \\
\hline $\begin{array}{l}\text { Paracamallanus cyathopharynx } \\
\text { (Female) (Baylis, 1923) }\end{array}$ & $\begin{array}{c}\text { Intestine of } \\
\text { Clarias gariepinus }\end{array}$ & $\begin{array}{l}\text { - worm was yellowish in color, provided } \\
\text { with well cleared transverse cuticular } \\
\text { striations. } \\
\text { The oral opening was marked by nine } \\
\text { longitudinal chitinous ribs that extended } \\
\text { to the base of tridents; the buccal } \\
\text { capsule was large, funnel-shaped and } \\
\text { was moderately sclerotized posterior } \\
\text { ends. Pharynx was sub-globular } \\
\text { followed by the cylindrical oesophagus. } \\
\text { In the female, the uterus of gravid } \\
\text { females was filled with larvae and the } \\
\text { vulva opening nearly at the middle of } \\
\text { the worm. Tail was conical in shape, } \\
\text { ending in three small cone-shaped } \\
\text { processes. }\end{array}$ & $\begin{array}{l}\text { Plate (1) } \\
\text { Fig. A, B } \\
\text { \& C }\end{array}$ \\
\hline $\begin{array}{c}\text { Procamallanus laeviconchus } \\
\text { (Female) } \\
\text { (Wedl, 1862) }\end{array}$ & $\begin{array}{c}\text { Stomach of } \\
\text { Clarias gariepinus }\end{array}$ & $\begin{array}{l}\text { - The buccal capsule was chitinous. } \\
\text { The mouth opening was quadripapillated } \\
\text { and its margin was provided with fine } \\
\text { cuticular membrane. In female; the } \\
\text { uterus of gravid female was filled with } \\
\text { first stage larvae. } \\
\text { - The tail was conical in shape. }\end{array}$ & $\begin{array}{c}\text { Plate (2) } \\
\text { Fig. (A)\&(B) }\end{array}$ \\
\hline $\begin{array}{l}\text { Contracaecum sp. } \\
\text { (Rudolphi, 1809) }\end{array}$ & $\begin{array}{c}\text { Intestine of Oreochromis } \\
\text { niloticus, } \\
\text { Clarias gariepinus and } \\
\text { Lates niloticus }\end{array}$ & $\begin{array}{l}\text { - The cuticle was finely serrated; it had } \\
\text { one boring tooth anteriorly. } \\
\text { - Intestinal caecum run anteriorly and was } \\
\text { longer than ventricular appendix which } \\
\text { runs posteriorly. Tail was short, had } \\
\text { retractile tip bearing small spines at the } \\
\text { posterior end. Anal opening was sub- } \\
\text { terminal and laying anterior to the end } \\
\text { of the body }\end{array}$ & $\begin{array}{l}\text { Plate (3) } \\
\text { Fig. A, B \& C } \\
\text { Fig. (1) }\end{array}$ \\
\hline $\begin{array}{l}\text { Dichelyne niloticus } \\
\text { (Mohamadain, 1989) }\end{array}$ & $\begin{array}{c}\text { Intestine of } \\
\text { Lates niloticus }\end{array}$ & $\begin{array}{l}\text { - It had a small, elongated body and } \\
\text { covered with transversally striated } \\
\text { cuticle. The oesophagus was entirely } \\
\text { muscular, dilated anteriorly to form a } \\
\text { false buccal capsule. The intestine was } \\
\text { extend posteriorly and was provided } \\
\text { with a single intestinal caecum which } \\
\text { was blind. In male; the tail was conical, } \\
\text { sharply pointed and slightly curved } \\
\text { ventrally and had two equal copulatory } \\
\text { spicules. }\end{array}$ & $\begin{array}{l}\text { Plate (4) } \\
\text { Fig. (A) \& (B) }\end{array}$ \\
\hline
\end{tabular}

Kafrelsheikh Vet. Med. J. Vol. 13 No. 1 (2015) 


\section{DISCUSSION}

The present investigation idicated that out of 216 examined fish, 28 samples proved to be infected with nematode parasites at Qena Governorate with total infection rate of $13 \%$. Concerning the fish species, the obtained results showed that Lates niloticus. had the highest infection rate $(27.8 \%)$, followed by Clarias gariepinus $(8.3 \%)$, while Oreochromis niloticus represented the lowest percent of infection $(2.8 \%)$.

\section{I- Tilapia sp.:}

The prevalence rate of nematode in Tilapia sp. (Contracaecum sp.) was $2.8 \%$. This result was nearly similar to that recorded by Aloo (2002) (2.0\%) and not in accordance with that reported by Momen (1992) (8.9\%), Al-Bassel (2003) (6.22\%), Yimer (2000) (15.56\%), Mokhtar (2000) (17.9\%), Yimer and Enyew (2003) 59.8\% at Lake Tana, Ethiopia, and Kaddumukasa et al. (2006) $62 \%$ at Lake Wamala, Uganda. On contrary, it was higher than that found by Daniela (2009) (1.6\%) in Ethiopia.This might be due to the maturation of parasites in large number of piscivorous birds around the lakes which allow parasites to reproduce more and infect large number of fish hosts. Additionally, almost all fish caught were eviscerated along the shore and washed into the lake causing recontamination of the lake that in turn increases parasite burden per fish.

In respect to their seasonal dynamics, the present results showed that the prevalence of nematode was $0 \%, 0 \%, 5.6 \%$ and $5.6 \%$ in Winter, Spring, Summer and Autumn respectively. This result was not in line with that revealed by Walaa (2004) who found that nematodes infection reached their maximum infection rate during Summer (12.6\%) and their minimum rate in Autumn (2.5\%). Seasonal changes in the Water environment (such as temperature, conductivity and $\mathrm{pH}$ ) can affect the occurrence of aquatic host parasites and infection rate of the parasites Moller (1978). 


\section{II- Clarias lazera:}

With reference to of nematode in Clarias lazera, the obtained results showed that the prevalence rate was $8.3 \%$. Similar results for some extent were obtained by Ismail (1980) (6\%), Hoda (1989), (5.5\%), Mokhtar (2000) $9.4 \%$ in El-Abassa farm, Ayanda (2009b) (6.25\%) in Ilorin. However, the present study was lower than that recorded by Aboul-hag (1985) (12.5\%), Walaa (2004) $14.7 \%$ in Sharkia Governorate, and Rasha (2010) who mention that the overall prevalence was $21.7 \%$ in Assuit Governorate .This may attributed to the reverse environmental factors affecting the infecting stage of these nematodes as well as was due to environmental factors such as feeding habits and changes in temperature.

Dealing with their seasonal dynamics, the highest infection rate was recorded in Summer and Autumn (11.1\%), followed by 5.6\% in Winter and Spring. This result was nearly in accordance with Alyan et al.(1994) who recorded the prevalence of nematodes in different seasons were $5 \%$ ,3.5\%, 3.5\% and 3\% in Summer ,Autumn, Spring and Winter respectively. Also agree with results of Walaa (2004) who found that nematodes reach their maximum infection rate during summer $(12.6 \%)$ and reach their minimum infection rate in autumn $(2.5 \%)$, while that of Rasha (2010) concluded that the prevalence rate of infection with nematodes in C. gariepinus was higher in Summer (25\%) than Spring, Autumn $(23.3 \%)$ and Winter $(15 \%)$. This may reflect a reduced feeding activity of the fish at low temperatures, reducing the chances of infection via copepods as well as to physico-chemical factors of the water body

In respect to the nematode species, 3 species were identified in this study infecting Clarias lazera at Qena Governorate.

The prevalence of Paracamallanus cyathopharynx in Clarias lazera was $2.8 \%$. This result was nearly in line with that reported by Ayanda and Opeyemi Isaac (2009) who found the infection rate was $\overline{\bar{K} \text { Kafrelsheikh Vet. Med. J. Vol. } 13 \text { No. } 1 \text { (2015) }}$ 
5.6\% and Akisanya (2013) who found the infection rate was $4.75 \%$. Eissa et al (2010) who found the infection rate was $31 \%$ from Ismailia Province. While, the prevalence of Procamallanus laeviconchus in Clarias lazera was $2.8 \%$. This result was higher than that mentioned by Oniye et al. (2004) who recorded the prevalence was $0.83 \%$ in Zaria, Nigeria and Sudhir kumal (2013) who recorded the prevalence was $3.33 \%$. On the contrary, the present investigation was lower than that recorded by Imam (1971) who recorded the prevalence was $20.45 \%$ and Eissa et al. (2010) who recorded the prevalence was $26 \%$ from Ismailia Province.

But the prevalence rate of Contracaecum sp. was $2.8 \%$; this result was agreed for some extent with Yimer (2000) who recorded the prevalence $5.33 \%$ and not agreed with that obtained by Yimer and Enyew (2003) who recorded the prevalence $41.94 \%$ at Lake Tana, Ethiopia.

\section{III- Lates niloticus}

In respect to the parasite recovered from Lates niloticus, only 2 species of nematodes. The prevalence rate of nematode was $27.8 \%$. The obtained data was higher than that recorded formerly Momen (1992) (5.7\%) in Sohag Governorate, Mokhtar (2000) (19.1\%) in El-Abassa farm, Onyedineke et al (2010) (0\%) in and Ahmed et al (2012) (0\%) in Al-Rahad River.

So the obtained results showed that the prevalence of Dichelyne niloticus in Lates niloticus was $4.2 \%$. This result was agreed with that reported by Momen (1992) who recorded the prevalence of Dichelyne niloticus in Lates niloticus was 5.7\% in Sohag Governorate.

In respect to Contracaecum sp.; the prevalence rate was $26.4 \%$. No available data about the host fish species. Contracaecum larvae were difficult to differentiate into species because the reproductive organs of 
Studies On Nematode Parasites Infecting Freshwater Fish In ...

the worms, which are used for characterization, were not yet fully developed except when using molecular analysis or alternatively infecting experimental hosts to obtain adult worms.

In respect to the morphological description of the recovered parasites in this study were similar to that previously illustrated by Rudolphi (1819); Wedl, Paperna, (1960); Ukoli, (1966); Khalifa et al., (1972); Mandour et al., (1988); Lamarck, (1801).

\section{LEGENDS TO FIGURES}

\begin{tabular}{|c|c|}
\hline Abbreviation & Explanation \\
\hline \multicolumn{2}{|c|}{ Nematode } \\
\hline $\mathbf{A}$ & Apex \\
\hline An & Anus \\
\hline B.C & Buccal capsule \\
\hline B.T & Boring tooth \\
\hline C.R & Cutical striation \\
\hline C.S & Copulatory spicules \\
\hline Es & Esophagus \\
\hline F.B.C & False buccal capsule \\
\hline I & Intestine \\
\hline I.C & Intestinal caecum \\
\hline $\mathbf{L}$ & Larvae \\
\hline $\mathbf{P h}$ & Pharynx \\
\hline $\mathbf{V}$ & Vulva \\
\hline V.A & Ventricular appendix \\
\hline Ve & Ventriculus \\
\hline C.G & Cement gland \\
\hline $\mathbf{E}$ & Eggs \\
\hline G.L & Genital ligament \\
\hline $\mathbf{H}$ & Hooks \\
\hline $\mathbf{L}$ & Lemnisci \\
\hline $\mathbf{P}$ & Proboscis \\
\hline P.R & Proboscis receptacle \\
\hline $\mathbf{T}$ & Testes \\
\hline Name & $\overline{\text { Syn }}$ \\
\hline Clarias lazera & $=$ Carias gariepinus \\
\hline Tilapia sp & $=$ Oreochromis niloticus \\
\hline
\end{tabular}

$\overline{\text { Kafrelsheikh Vet. Med. J. Vol. } 13 \text { No. } 1 \text { (2015) }}$ 


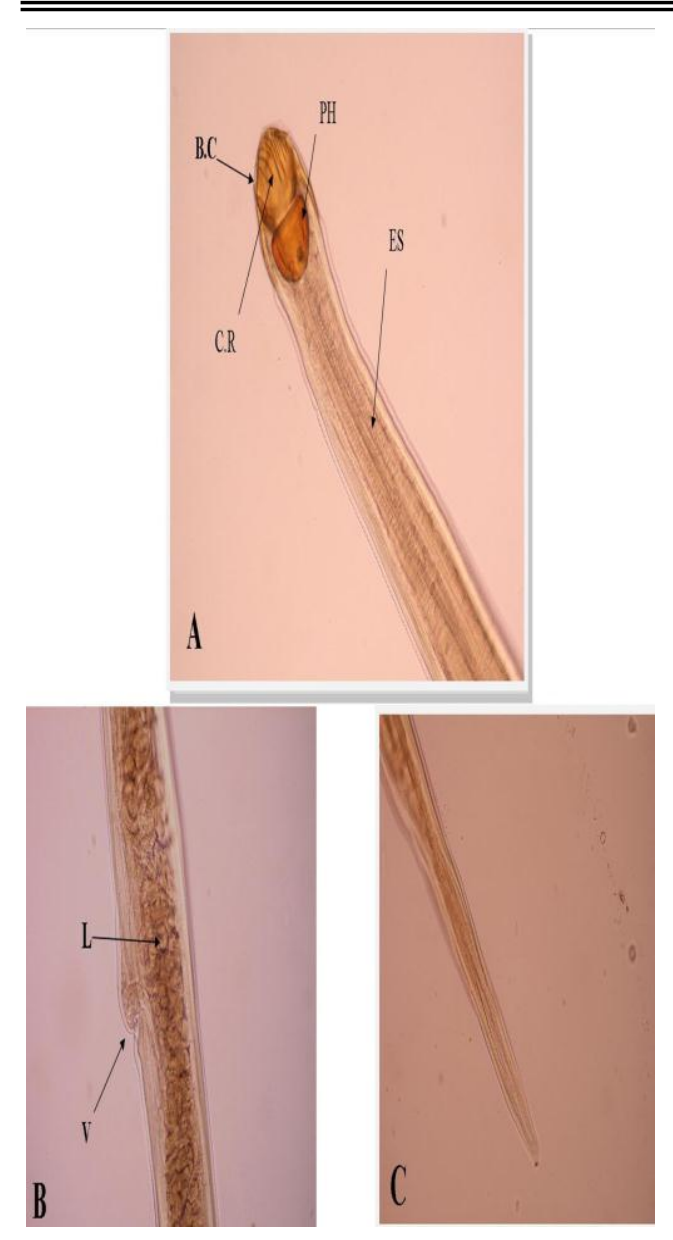

Plate (1)

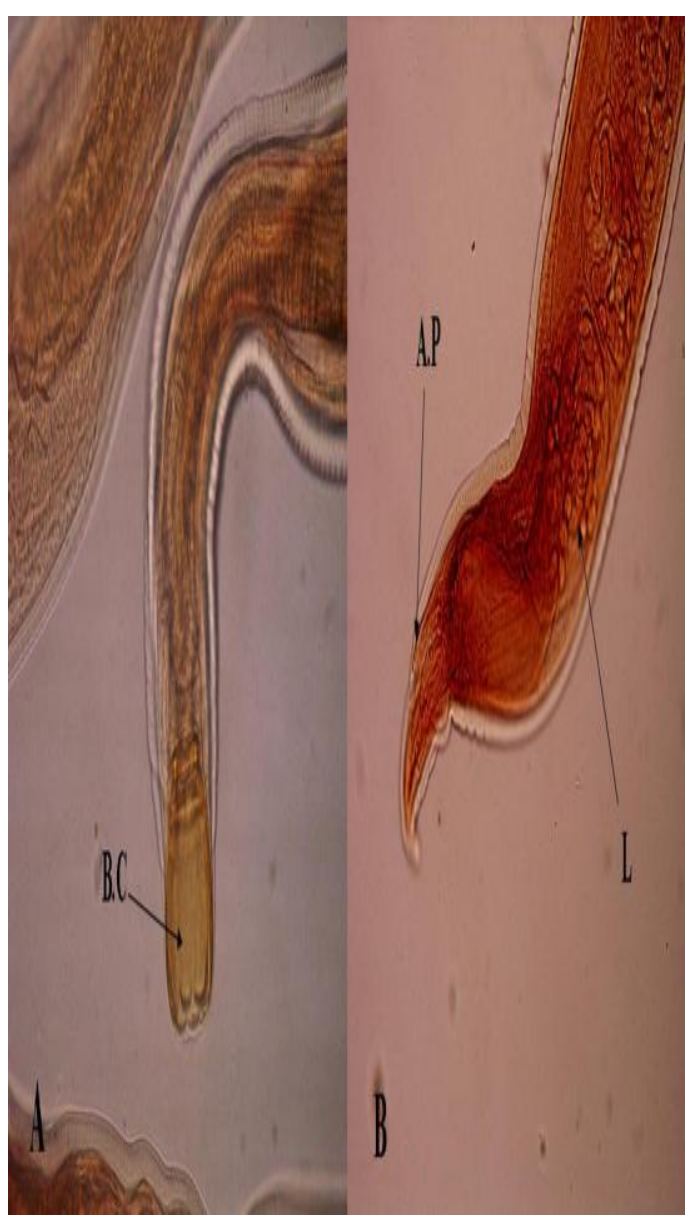

Plate (2)

Fig. (A): Paracamallanus cyathopharynx Fig. (A): Procamallanus laevionchus (Ant.end $x$ 40) (Ant. end $x$ 40)

Fig. (B): Paracamallanus cyathopharynx Fig. (B): Procamallanus laevionchus (Female $x$ 40) (Post. end Female x 40)

Fig. (C): Paracamallanus cyathopharynx Fig. (B): Procamallanus laevionchus (Post. end Female x 40) (Post. end female $x$ 40) 


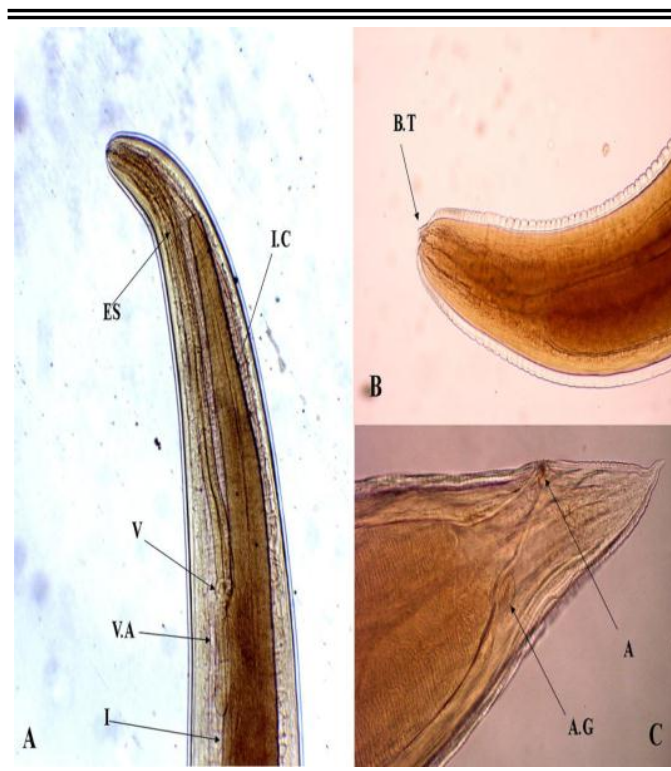

Plate (3)

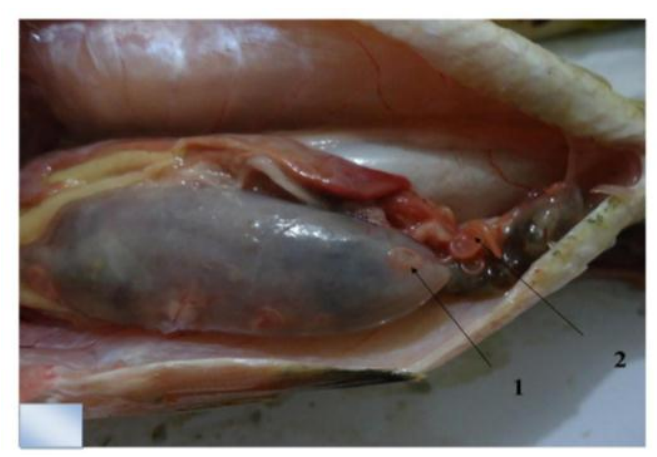

Fig. (A): Contracaecum sp. (x 4)

Fig. (B):Contracaecum sp.(Ant.end) (x10)

Fig.(C):Contracaecum sp.(Post.end) (x40)

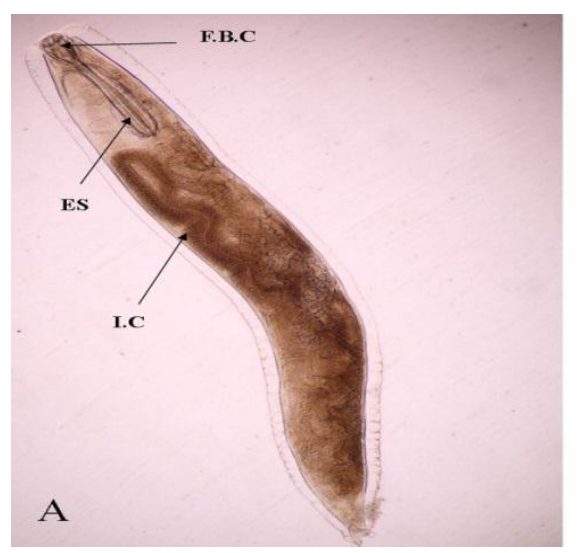

Fig.(1): Contracaecum sp. larvae in Lates niloticus in:

\section{1- Stomach wall}

2- Body cavity

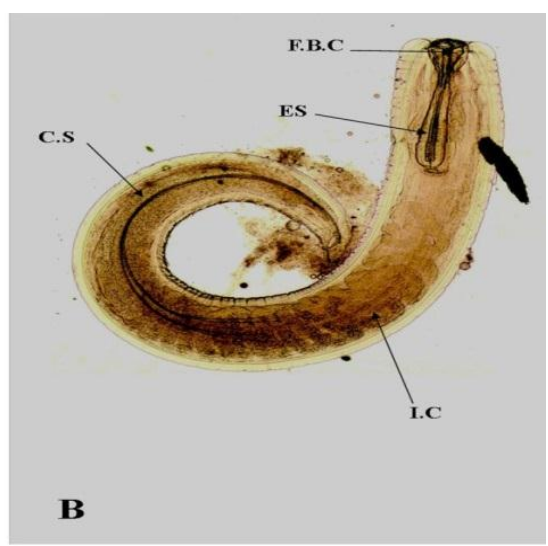

\section{Plate (4)}

Fig. (A): Dichelyne niloticus (Female) (x4)

Fig. (B): Dichelyne niloticus (Male) (x4)

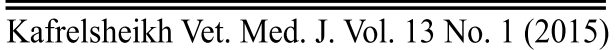




\section{REFERENCE}

- Abu El-Hag, S. T. (1985): Studies on the Helminth Parasites of Some Fishes from Sharkia Governorate. M. Sc. Thesis, Fac. Sci., Zagazig University.

- Ahmed H. S, Mohammed A. F and Mohammed S. R (2012): Survey of Helminthes Parasite of Four Fish Species in Al-Dinder and AlRahad River. Open Access Scientific Reports 1:517.Volume 1.

- Akinsanya, B. and Otubanjo, O.A. (2006): Helminth Parasites of Clarias gariepinus (Clariidae) in Lekki Lagoon, Lagos, Nigeria. Revista de Biologia Tropical, 54(1): 93-99.

- Al-Bassel, D.A.H.M. (2003): A general survey of the helminth parasites of fish from inland waters in the Fayoum Governorate, Egypt. Parasit. Res., 90: 135-139.

- Aloo P.A. (2002): A comparative study of helminth parasites from the fish Tilapia zillii and Oreochromis leucostictus in Lake Naivasha and Oloidien Bay.Kenya Journal of Helminthology 76, 95-102.

- Alyan, S.A.; Mahmoud, N.A. and Sahlab, A.A. (1994): Seasonal variation of enteric parasitism in Armout catfish Clarias lazera, freshwater fish at El-Minia Governorate ,Egypt. Beni -Suef ,Vet. Med. Res. Vol. IV, No. 1/1, 144- 153.

- Ayanda, O. I. (2009a): Comparison of parasitic helminthes infection between the sexes of Clarias gariepinus from Asa dam lorin, northcentral Nigeria .Scientific Research and Essay Vol. 4 (4), pp. 357-360. 
- Ayanda, O. I. (2009b): Comparative parasitic helminth infection between Cultured and wild species of Clarias gariepinus in Ilorin.North - Central Nigeria Scientific Research and Essay Vol. 4 (1), pp. 018-021.

- Belding, D.A. (1965): Text book of parasitology. $3^{\text {rd }}$ edition. Appleton-Century-Croft. Medredith publishing company, New York.

- Daniela, F.; Andrea, G.; Monica C.; Francesco T.;Francesco Q.;Robert K.; Tanja N. (2009): Veterinary and public health aspects in tilapia (Oreochromis niloticus niloticus) aquaculture in Kenya, Uganda and Ethiopia. Ittiopatologia, 2009, 6: 51-9351.

- Dezfuli, B. S.; Luisa G.; Robert, K.; Paul, J. and Maurizio, M. (2003): Immunohistochemistry, ultrastructure and pathology of gills of Abramis brama from Lake Mondsee, Austria, infected with Ergasilus sieboldi (Copepoda). Diseases of Aquatic Organisms 53: 257-262.

- Easa, M. El-S.; Faisal, M. and Imam, E. A. (1989): A recurrent epizootic of Ergasillosis in Tilapia (Oreochromis aureus) Tilapia zilli and the Gray Mullet (Liza ramada) in a brackish-water fish farm at Port Said, Egypt. Vet. Med. J. Giza, 37 (3): 361-372.

- Imam, E.A. (1997): Studies on parasites of Egyptian cultured fish. M. D. Fac. Vet. Med. Cairo Univ.

- Ismail, M. H.(1980): Studies on certain parasites of some fishes from lake Nasser at Aswan., A.R., Egypt. M. V. Sc. Thesis ,Department of Zoology .Fac Sci ,Assiut Univ. 
- Kaddumukasa, M.; Kaddu, J.B. and Makanga, B. (2006): Occurence of nematodes in the Nile Tilapia Oreochromis niloticus in Lake Wamala, Uganda. Ug. J. Agric. Sci.,12(2): 1-6.

- Khalifa, L.F. (1969): Studies on the helminth parasites of freshwater fishes of the Sudan . J. Zool., Lond. 158, 143-170.

- Mandour, A.M.; El-Naffar, M.K.;Abdel-Aal, A.A. and Abed, G.H. (1988): Henneguya assuiti $\mathrm{n}$. sp. in the fish Clarias lazera from the River Nile of Assiut. Proc 3rd Sci. Cong Fac Vet Med Assiut Univ 2022.p.387-39.

- Mokhtar, I. A. (2000): Studies on fish parasites from some fish farms in Egypt, Ph.D.Thesis, Faculty of science Ain-Shams univ, Egypt.

- Momen, E.E. (1992): Studies on some of the parasites in some Nile Fishg in Sohag Governorate .Ph. D. Thesis, Faculty of science., Sohag, Assuit. Univ.

- Oniye SJ, Adebote DA and Ayanda OI (2004): Helminth parasites of Clarias gariepinus (Teugels) in Zaria, Nigeria. J. Aquatic Sci. 19(2):71-75.

- Onyedineke, N. E.; Uchechukwu ,O.; Ofoegbu, P. U. and Ukogo, I.(2010): Helminth Parasites of some Freshwater Fish from River Niger at Illushi, Edo State, Nigeria. Journal of American Science: 6(3), 16-21.

- Rasha, S. A. (2010): Parasitological survey on African sharp tooth cat fish (Clarias gariepinus).M. V. Sc. Thesis, Fish Diseases and Management .Fac Vet. Med. Assiut univ. 
- Ravichandran, S., T.T.; Ajithkumar, P.R.; Ross and Muthulingam, M. (2010): Histopathology of the infestation of parasitic isopod Joryma tartoor of the host fish Parastromateus niger Res. J. Parasitol.,5(4): 303-306.

- Sudhir, K. L. (2013): Comparision of helminth infection between the sexes of Clarias batrachus (LINN.) from Rupandehi, Nepal. Int J Appl Sci Biotechnol, Vol. 1(2) : 71-73

- Ukoli, F.M. (1966): On the life history, growth and development from the metacercarial stage to the adult hood of Clinostomum tilapiae J. Helminthol., 40:215-226.

- Walaa, F.A.E. (2006): Gill affections in catfish (Clarias gariepinus) in Qena- Egypt. M.V.Sc. Thesis, Fish Diseases and Management .Fac Vet. Med., South Valley University.

- Wedl, K. (1862): Zur Helminthen-fauna Aegyptien Sitzungsber. Math-L Naturw, K. Akad. Wiss Wien, 44:463-482. Boulenger (cypriniformis :Clariidae) in Zambia, Africa. Proc. Helm. Soc. Wash., 34(2): 125-128.

- Yimer, E. (2000): Preliminary survey of parasites and bacterial pathogens of fish at lake Ziway. Ethiop. J. Sci., 23 (1): 25-33.

- Yimer, E. and Enyew, M. (2003): Parasites of fish at Lake TanarEthiopia. Ethiop. J. Sci., 26 (1): 31-36. 
در اسات حول الديدان الاسطو انية التي تصيب أسماك المياه العذبة في محافظة قنا محمود الصيفى" اسماعيل سعد الشهاوي" " أسماء متولي " " مروة فواز "." كلية الطب البيطري، قسم الطفيليات، جامعة كفر الثيخ " جامعة جنوب الوادي، " مصر.

قد أجريت هذه الدراسة على الديدان الاسطوانية التي تصيب أسماك المياه العذبة في محافظة قنا. بما في ذلك الإنتشار الموسىى ـ كثافة الإنتثار ومعرفة الأنواع المختلفة. تبين أن "معدل العدوى من مختلف الديدان الخبطية الطفيليات بين أسماك المياه العذبة في محافظة قنا كان (13\%). وكان لاتس النيلي لديه أعلى معدل العدوى (27.8\%)، يليه القرموط (3.8\%) ثم البلطي النيلي (2.3\%). وفيما يتعلق انتشار الثتاء الموسمية لديها أعلى معدل العدوى تليها الخريف ثم الصيف والربيع. ثم التعرف على أربع أنواع من الديدان الاسطوانية. وسجلت دودة الباراكمالينيس نسبة(2.8\%) كما سجلت دودة البروكمالينيس نفس النسبة وذلك فى سكة القرموط. وسجلت يرقات الكونترا سيكم نسبة (2.8٪) في أسماك البلطي النيلي والقرموط و (26.4٪) في الاتس النيلي وديشلان النيلى(4.2\%) في الاتس النيلي.وكانت متوسط الكثافة للإصابة ليرقات الدودة الخيطبة بين أسماك البلطي النيلي، القرموط والاتس النيلي 2\% و 22 \% و 20 \% على التوالي. 